\title{
My Times with Professor Igor Kregar and some Hydrolytic Enzymes
}

\author{
Karl J. Kramer* \\ Department of Biochemistry and Molecular Biophysics, Chalmers Hall, Kansas State University, \\ Manhattan, Kansas 66506 USA \\ * Corresponding author: E-mail: kkramer1@cox.net; \\ Tel: +1 7855395975
}

Received: 01-21-2019

Dedicated to the memory of Prof. Dr. Igor Kregar

\begin{abstract}
The late Professor Igor Kregar and this author had several overlapping biochemical research interests. One focus was the glycoside hydrolase, lysozyme, and the other was proteolytic enzymes and their inhibitors, in particular those present in tissues from insects and plants. Regarding lysozyme our results helped to understand its catalytic mechanism and the carboxylic acid functional groups involved. Another area was insect-plant interactions involving defensive responses of plants to insect feeding via proteolytic enzyme inhibitors. Those results can be utilized in transgenic plant and seed biotechnological applications, which would help to reduce damage to plants and seeds caused by coleopteran and other insect pests. Also described are some cultural and travel interactions that the author benefited from his friendship with Professor Kregar.
\end{abstract}

Keywords: Lysozyme; catalysis; mechanism; proteases; inhibitors; beetles; potato; resistance

\section{Introduction}

My interactions with the late Slovenian scientist Professor Igor Kregar began more than 50 years ago. We met in Tucson, Arizona, USA, where he had arrived in the late 1960s from Ljubljana, Slovenia (then Yugoslavia) to begin working in the Department of Chemistry at the University of Arizona with Professor John A. Rupley. Igor was the second of three postdoctoral researchers from the Jozef Stefan Institute in Ljubljana to work in Rupley's laboratory during my tenure there as a graduate student. Franc Gubensek was the first postdoctoral scholar to work there and Vito Turk the third. After each initial meeting, valued friendships were established with all three Slovenes, all of which were maintained long thereafter, and in Igor's case, our friendship lasted a very long time until his untimely death in 2017.

\section{Research Time}

Igor had a long list of scientific publications. ${ }^{1}$ In $\mathrm{Ru}-$ pley's laboratory Igor and I both worked on protein chemistry projects focused on the structure and function of a glycosidic enzyme, hen's egg white lysozyme, he on the dependence of $\mathrm{pH}$ on the hydrolysis of the chitohexasaccharide substrate ${ }^{2}$ and myself on the relative chemical reactivity in aqueous solution and acidic methanol of its ten carboxylic acids, several of which are involved in substrate binding and the catalytic mechanism. ${ }^{3,4}$ Results from Igor's research supported the hypothesis that non-productive enzyme-substrate complexes are of kinetic importance and that the structure of the productive complex and the catalytic mechanism were those suggested by results obtained from the $\mathrm{x}$-ray crystallographic enzyme and enzyme-substrate complex structures. Results from my experiments revealed that the two carboxyl groups present in the active site of lysozyme, which were indicated by the crystallographic structures to participate in the catalytic mechanism, were more reactive to nucleophilic chemical modification than any of the other eight carboxyl groups.

During our subsequent scientific careers, both Igor and I became interested in another type of hydrolytic enzyme, the proteolytic enzymes and also their inhibitors. He studied several kinds of proteases and inhibitors obtained from a wide array of sources such as microbes, cows, rats, pigs, sheep, marine animals, plants and insects. My labo- 
ratory was more focused on proteases and their inhibitors that were present in insect and plant tissues. Our interests overlapped in the area of insect-plant interactions involving defensive responses of plants to insect feeding via proteolytic enzyme inhibitors. Igor published several papers dealing with proteolytic enzymes and inhibitors in the potato, Solanum tuberosum as well as the cysteine proteases in the gut of Colorado potato beetle, Leptinotarsa decemlineata..$^{5-10} \mathrm{He}$ and his collaborators found that the beetle's cysteine proteolytic activity was insensitive to potato protease inhibitors, enabling the insects to overcome this defense mechanism of potato plants. They then looked for inhibitors from other sources that would be more effective against the beetle's proteases. ${ }^{5}$ After testing several proteinaceous inhibitors of different structural types for their ability to inhibit the beetle's proteolytic activities in vitro, most members of the cystatin superfamily of inhibitors ${ }^{11}$ were found to be poor inhibitors of the beetle's induced endoproteolytic activities except for the third domain of human kininogen, which was a fairly strong inhibitor. The best inhibitor of the beetle's induced endoproteolytic activity was one of the structurally different thyroglobulin type1 domain-like inhibitors, equistatin, a protease inhibitor from the sea anemone, Actinia equine. ${ }^{12-14}$ The stefin family of inhibitors in the cystatin superfamily was inhibitory of the beetle's induced aminopeptidase-like activity. In in vivo feeding experiments, larvae of the Colorado potato beetle fed on equistatin-coated potato leaves were strongly retarded in their growth and development with about half of the larvae dying after only a few days. Igor's results demonstrated the potential of using thyroglobulin type-1 domain-like and stefin family-like inhibitors as potential field crop protectants against insect attack. ${ }^{5}$

A related insect control project involved a collaboration between not only Slovenian and American scientists but also several Japanese scientists on a study of the effects of proteinase inhibitors on the growth and digestive proteolysis of another coleopteran, the red flour beetle, Tribolium castaneum..$^{15}$ Inhibitors of T. castaneum digestive proteinases were examined to identify potential biopesticides for incorporation into transgenic plants and seeds thereof. Cysteine proteinase inhibitors from potato, Job's tears and sea anemone (equistatin) were effective inhibitors of in vitro casein hydrolysis by $T$. castaneum proteinases (Fig. 1).

Similar to Igor's findings with the Colorado potato beetle, the thyroglobulin type-1 domain was the inhibitor domain most active toward red flour beetle gut proteases. Casein hydrolysis was inhibited weakly by chymostatin and soybean trypsin inhibitor. The soybean trypsin inhibitor had no significant effect on growth when it was bioassayed alone, but it was effective when used in combination with a potato cysteine proteinase inhibitor. In oral feeding bioassays with single inhibitors, larval growth was suppressed by the cysteine proteinase inhibitors from potato, Job's tears and sea anemone. Levels of inhibition were similar to that observed with a low molecular weight model cysteine protease inhibitor, E-64, although the moles of proteinaceous inhibitors tested were many fold less. These proteinaceous inhibitors were identified to be candidates

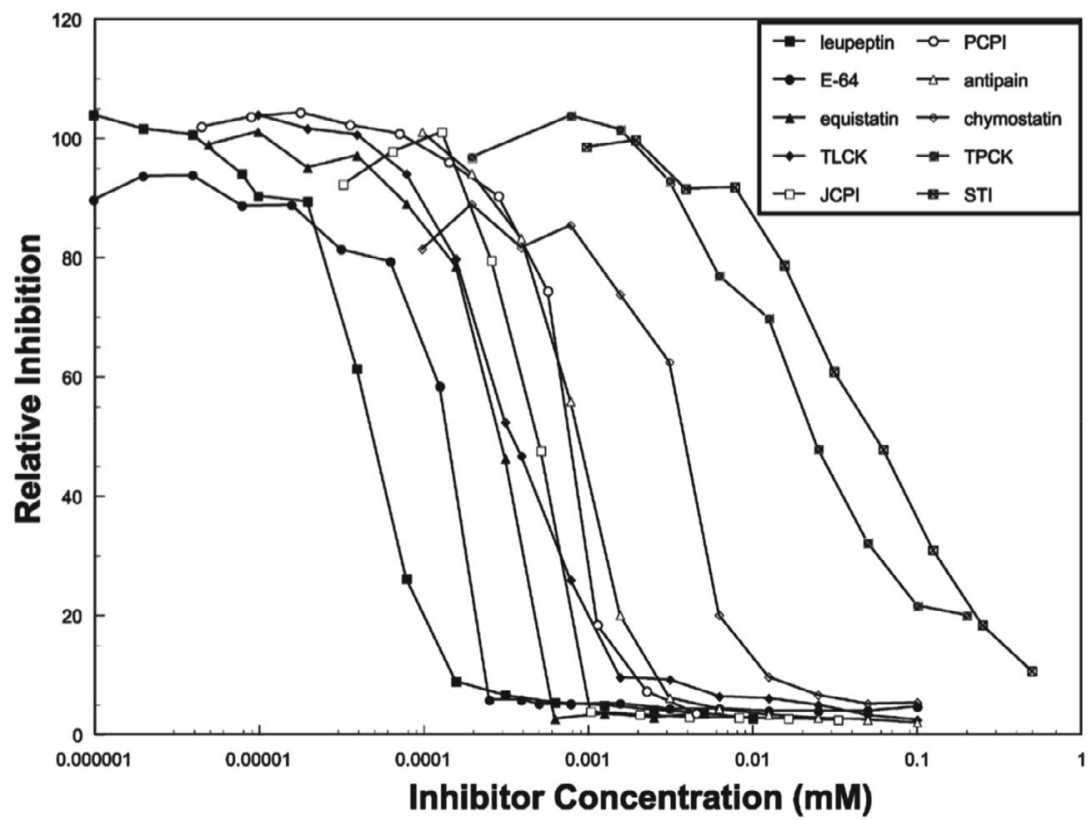

Figure 1. Relative inhibition (as a percent of the control activity) of casein hydrolysis by Tribolium castaneum larval gut proteinases with selected proteinase inhibitors ${ }^{15}$ including E-64: L-trans-epoxysuccinylleucylamido w4-guanidinox butane; JCPI, Job's tears cysteine proteinase inhibitor; TLCK, tosyl-L-lysine chloromethyl ketone; TPCK, $N$-tosyl-L-phenylalanine chloromethyl ketone; PCPI, potato cysteine proteinase inhibitor and STI, soybean trypsin inhibitor (Kunitz). Leupeptin, E-64, equistatin and TLCK were the most potent caseinolytic enzyme inhibitors. In feeding bioassays, equistatin and PCPI were the most potent peptides in inhibiting larval growth of the red flour beetle. ${ }^{15}$ 
for transgenic plant and seed technology to reduce damage by coleopteran pests such as the red flour beetle and Colorado potato beetle.

Overall, from a practical viewpoint, Igor's and other findings further illustrated the striking diversity of possible protease-inhibitor interactions in insect-plant systems and underline the relevance of protease inhibitor activity-based protease profiling to characterize the inhibitory range of recombinant inhibitors considered for insect pest control. For example, a straightforward way to use cystatin-like inhibitors against coleopteran insects might be to combine them with serine protease inhibitors in such a way as to significantly broaden the overall spectrum of target protease types and minimize the effectiveness of any physiological compensatory processes in the herbivores. ${ }^{16,17}$

\section{Cultural and Travel Times}

In addition to our scientific interactions, I gained much information from not only Igor but also Vito and Franc about the history, politics and geography of Slovenia/Yugoslavia and the Balkan region. Until that time, I knew very little about their country, but because of their generosity, I came to appreciate its greatness and wonderful citizens. All three are/were very good ambassadors for Slovenia.

One of the more memorable times spent with Igor was when he joined my wife Virginia and myself on a Mexican railroad trip south to Guadalajara and Mexico City where we enjoyed many cultural attractions and savored many kinds of delicious Mexican dishes. Afterwards, Igor became quite the connoisseur of Mexican cooking and loved to prepare Mexican food for his family and friends in Slovenia. We would even mail him care packages containing Mexican food items that at that time were hard to find in Slovenia. A very special travel time with Igor for me was a visit to Ljubljana when he helped to host me and to enjoy the natural beauty and culture of that area of Slovenia. Another happy travel memory of Igor was one regarding the car he had bought and drove in Tucson. He was very delighted to be the owner of a 1961 white Buick LeSabre convertible and enjoyed cruising around Arizona very much with the top down while taking in the warm southwestern sunshine.

\section{Quality of Life Time}

One of the greatest gifts of life is friendship, and I received that and more from Professor Kregar. He added much to my quality of life overall. As we grew older and in spite of living far apart, we spent many hours visiting via Skype on the internet, updating our activities, sharing stories and trying to find solutions to the world's problems.
Not only did I benefit scientifically from our friendship, I also became better educated in international history, geography, politics and culture because of Igor. I will always remember him as a wonderful colleague and friend with great love and respect.

\section{References}

1. PubMed, 2018, https://www.ncbi.nlm.nih.gov/pubmed?cm$\mathrm{d}=$ Search\&term=Kregar\%20I\%5BAuth\%5D

2. S. K. Banerjee, I. Kregar, V. Turk and J. A. Rupley, J. Biol. Chem. 1973, 248, 4786-92.

3. K. J. Kramer and J. A. Rupley, Arch. Biochem. Biophys. 1973, 156, 414-25. DOI:10.1016/0003-9861(73)90290-7

4. K. J. Kramer and J. A. Rupley, Arch. Biochem. Biophys. 1973, 158, 566-76. DOI:10.1016/0003-9861(73)90549-3

5. K. Gruden, B. Strukelj, T. Popovic, B. Lenarcic, T. Bevec, J. Brzin, I. Kregar, J. Herzog-Velikonja, W. J. Stiekema, D. Bosch and M. A. Jongsma, Insect Biochem. Mol. Biol. 1998, 28, 54960. DOI:10.1016/S0965-1748(98)00051-4

6. K. Gruden, B. Strukelj, M. Ravnikar, M. Poljsak-Prijatelj, I. Mavric, J. Brzin, J. Pungercar and I. Kregar, Plant Mol. Biol. 1997, 34, 317-23. DOI:10.1023/A:1005853026333

7. S. Kreft, M. Ravnikar, P. Mesko, J. Pungercar, A. Umek, I. Kregar and B. Strukelj, Phytochemistry 1997, 44, 1001-6. DOI:10.1016/S0031-9422(96)00668-1

8. D. B. Maganja, B. Strukelj, J. Pungercar, F. Gubensek, V. Turk and I. Kregar, Plant Mol. Biol. 1992, 20, 311-3.

DOI:10.1007/BF00014499

9. U. Schluter, M. Benchabane, A. Munger, A. Kiggundu, J. Vorster, M. C. Goulet, C. Cloutier and D. Michaud, J. Exp. Bot. 2010, 61, 4169-83. DOI:10.1093/jxb/erq166

10. B. Strukelj, J. Pungercar, P. Mesko, D. Barlic-Maganja, F. Gubensek, I. Kregar and V. Turk, Biol. Chem. Hoppe Seyler 1992, 373, 477-82. DOI:10.1515/bchm3.1992.373.2.477

11. V. Turk, V. Stoka and D. Turk, Front. Biosci. 2008, 13, 540620. DOI: $10.2741 / 3089$

12. B. Lenarcic, A. Ritonja, B. Strukelj, B. Turk and V. Turk, J. Biol. Chem. 1997, 272, 13899-903.

DOI:10.1074/jbc.272.21.13899

13. T. Bevec, V. Stoka, G. Pungercic, I. Dolenc and V. Turk, J. Exp. Med. 1996, 183, 1331-8. DOI:10.1084/jem.183.4.1331

14. T. Ogrinc, I. Dolenc, A. Ritonja and V. Turk, FEBS Lett. 1993, 336, 555-9. DOI:10.1016/0014-5793(93)80875-U

15. B. Oppert, T. D. Morgan, K. Hartzer, B. Lenarcic, K. Galesa, J. Brzin, V. Turk, K. Yoza, K. Ohtsubo and K. J. Kramer, Comp. Biochem. Physiol. C Toxicol. Pharmacol. 2003, 134, 481-90.

16. B. Oppert, T. D. Morgan, K. Hartzer and K. J. Kramer, Comp. Biochem. Physiol. C Toxicol. Pharmacol. 2005, 140, 53-8.

17. J. Vorster, A. Rasoolizadeh, M. C. Goulet, C. Cloutier, F. Sainsbury and D. Michaud, Insect Biochem. Mol. Biol. 2015, 65, 10-9. DOI:10.1016/j.ibmb.2015.07.017 


\section{Povzetek}

Nekateri interesi pokojnega profesorja Igorja Kregarja ter avtorja tega prispevka so se na področju biokemijskih raziskav prekrivali. Na eni strani glikozidne hidrolaze in lizocim na drugi strani pa proteolizni encimi in njihovi inhibitorji, prisotni $\mathrm{v}$ tkivih insektov in rastlin. $\mathrm{V}$ primeru lizocima so naši rezultati doprinesli $\mathrm{k}$ razumevanju njegovega katalitskega mehanizma, pri katerem funkcionalne skupine karboksilne kisline sodelujejo. Drugo področje pa zajema interakcije med insektom in rastlino, ki vključuje obrambne odgovore rastlin na prehrano insektov s pomočjo inhibitorjev proteoliznih encimov. Dobljeni rezultati so lahko uporabni pri biotehnološki aplikaciji transgenih rastlin in semen, kar naj bi pripomoglo k zmanjšanju škode, ki jo povzročajo Coleoptere in drugi insekti. Iz prikazanih skupnih interesov na področju kulture in potovanj avtor tega prispevka ocenjuje, da je veliko pridobil s prijateljstvom s profesor Kregarjem. 